\title{
AFLATOXIN M1 IN MILK AND ASSESSING THE POSSIBILITY OF ITS OCCURRENCE IN MILK PRODUCTS
}

\author{
Sandra Jakšići ${ }^{1 *}$, Milica Živkov Baloš ${ }^{1}$, Jasna Prodanov Radulović ${ }^{1}$, \\ Igor Jajićc ${ }^{2}$, Saša Krstović ${ }^{2}$, Igor Stojanov ${ }^{1}$, Zoran Mašić ${ }^{1}$ \\ ${ }^{1}$ Scientific Veterinary Institute „Novi Sad“, Novi Sad, Serbia \\ ${ }^{2}$ University of Novi Sad, Faculty of Agriculture, \\ Department of Animal Science, Serbia
}

\begin{abstract}
Aflatoxin M1 (AFM1) is a hepatocarcinogenic derivative of aflatoxin B1 excreted into the milk after ingestion of contaminated feed. The presence of AFM1 in milk and milk products is of huge concern for human health. In this paper, the results on long term assessment of AFM1 in milk produced in Serbia are presented. In the period 2013 to 2016, 427 milk samples were examined for AFM1. In $34.4 \%$ of samples, the content of AFM1 was higher than $0.05 \mu \mathrm{g} / \mathrm{kg}$. The article also offers a review of the fate of aflatoxin in milk products during the different operations in milk processing. The evaluation of the influence of processing on AFM1 stability can propose economic strategy for resolving cases of accidents due to AFM1 contamination of milk.
\end{abstract}

Key words: aflatoxin M1, milk, milk product

${ }^{1 *}$ Corresponding author: sandra@niv.ns.ac.rs 


\title{
AFLATOKSIN M1 U MLEKU I PROCENA MOGUĆNOSTI NJEGOVE POJAVE U PROIZVODIMA OD MLEKA
}

\author{
Sandra Jakšić ${ }^{\star}$, Milica Živkov Baloš ${ }^{1}$, Jasna Prodanov Radulović ${ }^{1}$, \\ Igor Jajić ${ }^{2}$, Saša Krstović ${ }^{2}$, Igor Stojanov ${ }^{1}$, Zoran Mašić ${ }^{1}$ \\ ${ }^{1}$ Naučni institut za veterinarstvo „Novi Sad“, Novi Sad, Srbija \\ ${ }^{2}$ Univerzitet u Novom Sadu, Poljoprivredni fakultet, Departman za stočarstvo, Srbija
}

\section{Kratak sadržaj}

Aflatoksin M1 (AFM1) je hepatokarcinogeni derivat aflatoksina B1 koji se izlučuje mlekom nakon uzimanja kontaminirane hrane. Prisustvo AFM1 u mleku i mlečnim proizvodima je od ogromnog značaja za ljudsko zdravlje. U ovom radu su prikazani rezultati dugoročnog ispitivanja AFM1 u mleku u Srbiji. U periodu od 2013. do 2016. godine, u 427 uzoraka mleka je ispitan sadržaj AFM1. U 34,4\% uzoraka sadržaj AFM1 je bio veći od $0,05 \mu \mathrm{g} / \mathrm{kg}$. U radu je takođe dat pregled istraživanja o sudbini aflatoksina u mlečnim proizvodima tokom različitih procesa tokom prerade kontaminiranog mleka. Utvrđivanje uticaja prerade mleka na stabilnost AFM1 može da obezbedi ekonomsku strategiju za rešavanje problema u slučaju kontaminacije mleka sa AFM1.

Ključne reči: aflatoksin $\mathrm{M} 1$, mleko, proizvodi od mleka

\section{INTRODUCTION}

Aflatoxins (AF) are the most important mycotoxins, and besides cereals, they can contaminate milk and milk products. International Agency for Research of Cancer evaluated aflatoxin M1 (AFM1) as proved carcinogen to humans, and considered it as belonging to Group 1 (IARC, 2002). Contamination of milk and milk products can occur by indirect contamination via contaminated feed or rarely by direct contamination, when molds grow on milk. There are different data about carry-over rate of aflatoxin B1 (AFB1) from feed to AFM1 in milk. According to Creppy (2002), approximately $0.3-6.2 \%$ of the total ingested AFB1 from feed is transformed into milk. Some investigations revealed different carry-over rate in different animals. For example, in cows, it ranges from $0.35 \%$ to $3 \%$, while in sheep this rate is 0.08 to $0.33 \%$ (Bakirci, 2001). 
AFM1 binds to the protein fraction of milk (casein (Brackett, 1982) and may be present in milk products produced from the contaminated milk in higher concentrations than in milk itself. Only combined action of heat and low $\mathrm{pH}$ is able to denature whey proteins to a point where they lost their AFM1binding capacity (Barbiroli et al., 2007). Due to its semi polar character, AFM1 predominate in the nonfat fraction (Van Egmond and Paulish, 1986; Galvano et al., 1996; Prandini et al., 2009). AFM1 was found in pasteurized milk, UHT milk, powdered milk, infant milk formulas, yoghurt, feta cheese, white cheese, traditional cheese from Turkey, Iran and Brazil, ice-cream, butter (Campagnollo et al., 2016). Different factors can influence the amounts of free AF in milk and milk products: aflatoxin concentration, $\mathrm{pH}$, heat processes, ionic strength, fermentation temperature, storage temperature, storage time, protein content, titratable acidity, strain utilized (Arab et al., 2012). Pasteurization processes, even those using UHT techniques, do not drastically affect AFM1 concentration because of its heat stability (Bakirci 2001; Galvano et al., 1996; Rama et al., 2015). The data from published studies showed variable findings regarding AFM1 reduction during different unit operations used in milk products processing (Camagnollo et al., 2016). There are opinions that these contraindications in aflatoxin stability studies are due to the differences in initial levels of contamination, the range of temperature and analytical methods for AF determination (Campagnollo et al., 2016).

The legislation for AFM1 in EU (EC 1881/2006) is very strict. Maximum level is $0.05 \mu \mathrm{g} / \mathrm{kg}$. In the USA (FDA, 2011), maximal limit for AFM1 in milk is $0.5 \mu \mathrm{g} / \mathrm{kg}$ as well as in Asia (China) and South America (Brazil). In Serbia, legislation for AFM1 in milk was in accordance with the EU in 2011, when the new Regulation about maximum permissible residues in food and feed was adopted („Službeni glasnik RS” 28/2011). However, since then, maximum level of AFM1 has been changed several times (Table 1). Currently, there is valid modification of the Regulation under which the maximum acceptable amount of AFM1 in milk is $0.25 \mu \mathrm{g} / \mathrm{kg}$. Except for milk, regulatory limits were established in some countries also for the presence of AFM1 in milk products (Table 2, Campagnollo, 2016). 
Table 1. Maximum permissible limits of AFM1 in milk in Serbia

\begin{tabular}{|c|c|c|}
\hline $\begin{array}{c}\text { Maximum } \\
\text { permissible } \\
\text { concentra- } \\
\text { tion }(\mu \mathrm{g} / \mathrm{kg})\end{array}$ & Reference & Period of validity \\
\hline 0.05 & „Službeni glasnik RS” 28/2011 & $04.05 .2011 .-01.03 .2013$. \\
\hline 0.5 & „Službeni glasnik RS” 20/2013 & $01.03 .2013 .-20.03 .2014$. \\
\hline 0.5 & „Službeni glasnik RS” 29/2014 & $20.03 .2014 .-01.07 .2014$. \\
\hline 0.05 & „Službeni glasnik RS” 39/2014 & $01.07 .2014 .-14.07 .2014$. \\
\hline 0.25 & „Službeni glasnik RS” 72/2014 & $15.07 .2014 .-31.12 .2014$. \\
\hline 0.05 & „Službeni glasnik RS” 29/2014 & $01.01 .2015 .-06.10 .2015$. \\
\hline 0.25 & „Službeni glasnik RS” 84/2015 & $07.10 .2015 .-05.04 .2016$. \\
\hline 0.25 & „Službeni glasnik RS” 35/2016 & $06.04 .2016 .-05.10 .2016$. \\
\hline 0.25 & „Službeni glasnik RS” 81/2016 & $06.10 .2016 .-05.03 .2017$. \\
\hline 0.25 & „Službeni glasnik RS” 21/2017 & $05.03 .2017 .-06.09 .2017$. \\
\hline
\end{tabular}

Table 2. Maximum permissible limits for AFM1 in milk and milk products in different countries (Campagnollo, 2016; Škrbić et al., 2015)

\begin{tabular}{|l|l|l|}
\hline \multicolumn{1}{|c|}{ Country } & Milk & \multicolumn{1}{c|}{ Milk product } \\
\hline USA & 0.50 & \\
\hline EU & 0.050 & \\
\hline Iran & 0.050 & 0.50 (milk powder) \\
\hline & & 0.020 (butter and butter milk) \\
\hline & & 0.250 (cheese) \\
\hline Turkey & 0.050 & 0.250 (cheese) \\
\hline Brazil & 0.50 & 5 (milk powder) \\
\hline & & 2.5 (cheese) \\
\hline Italy & 0.050 & 0.250 (soft cheese) \\
\hline & & 0.450 (hard cheese) \\
\hline China & 0.5 & 0.5 (milk powder) \\
\hline Pakistan & 0.05 & 0.050 \\
\hline Switzerland & 0.050 & 0.250 (cheese) \\
\hline Austria & 0.050 & 0.250 (cheese) \\
\hline France & 0.050 & 0.250 (cheese) \\
\hline The Netherlands & 0.050 & 0.020 (butter and cheese) \\
\hline
\end{tabular}


The presence of AF is typical for the warm tropical areas, and therefore the occurrence of these toxins has not been characteristic for the climate in Serbia (Živkov-Baloš et al., 2008). Due to climatic changes, as well as the development of novel analytical methods for its determination, the detection of aflatoxins in Serbian corn became more frequent (Jakšić et al., 2015). Consequently, the problems about the presence of AFM1 in milk are more pronounced. After the incident in 2013, when high contamination of corn and milk was recorded, special attention was given to the monitoring of food safety in terms of the presence of aflatoxins. As obvious from the introduction paragraph, the legislation in Serbia regulates the presence of AFM1 in milk, but not in milk products. Only few papers have been published on the topic of monitoring AFM1 in milk products in Serbia, but there are no specific studies on the transfer of AFM1 from milk into traditional and most widely consumed products in Serbia. This paper provides a long-term assessment of AFM1 in milk produced in Serbia and implications for possible fate of AFM1 in milk during its processing.

\section{MATERIAL AND METHODS}

In a period from 2013 to 2016, in the laboratory of Scientific Veterinary Institute „Novi Sad“, 427 milk samples were analyzed for the content of AFM1. Milk samples were collected from milk collecting points or dairy plants, directly on the production line. Samples were collected directly from the production in dairies or sampled by an official of control.

The presence of $\mathrm{AFM}_{1}$ was analyzed by enzyme-linked immunosorbent assay method, using Ridascreen Aflatoxin $\mathrm{M}_{1}$ (Art. No. R1121) test kit (R-Biopharm, Germany). The color intensity is measured photometrically at $450 \mathrm{~nm}$ (Multiskan FC, Thermo Scientific, China) and is inversely proportional to the mycotoxin concentration in the sample. Special software Rida Soft Win (Art. No. Z9999, R-Biopharm, Germany) was used for the evaluation of enzyme immunoassays. According to the manufacturer's description, the detection limit (DL) for $\mathrm{AFM}_{1}$ was $0.005 \mu \mathrm{g} / \mathrm{kg}$. Because of high toxin concentration and maximum permitted level of $0.5 \mu \mathrm{g} / \mathrm{kg}$, in a part of examinations the samples were diluted, thus in that case DL was $0.05 \mu \mathrm{g} / \mathrm{kg}$, while determination range encompassed concentrations from 0.05 to $0.80 \mu \mathrm{g} / \mathrm{kg}$.

The analytical quality of the ELISA method was assured by determination of spiked samples as well as by participation in proficiency testing scheme (milk powder sample FAPAS 04224). Recovery for AFM 1 was 105\%. 


\section{RESULTS}

The results of AFM1 content in milk samples (2013-2016) are presented in Table 3.

Table 3. Contents of $\mathrm{AFM}_{1}$ in milk samples in Serbia in 2013-2016

\begin{tabular}{|c|c|c|c|c|c|c|c|}
\hline \multirow[b]{2}{*}{ Year } & \multirow[b]{2}{*}{$\begin{array}{l}\text { Positive/ } \\
\text { total no. } \\
\text { of samples }\end{array}$} & \multirow[b]{2}{*}{$\begin{array}{c}\text { Positive } \\
\text { samples }^{*} \\
(\%)\end{array}$} & \multicolumn{5}{|c|}{ No. of samples } \\
\hline & & & $\begin{array}{c}<0.05 \\
(\mu \mathrm{g} / \\
\mathrm{kg})\end{array}$ & $\begin{array}{c}0.05- \\
0.25 \\
(\mu g / \mathrm{kg})\end{array}$ & $\begin{array}{c}0.26-0.50 \\
(\mu \mathrm{g} / \mathrm{kg})\end{array}$ & $\begin{array}{c}0.51-0.80 \\
(\mu \mathrm{g} / \mathrm{kg})\end{array}$ & $\begin{array}{c}>0.80 \\
(\mu \mathrm{g} / \\
\mathrm{kg})\end{array}$ \\
\hline 2013 & $55 / 75$ & 73.3 & 20 & 28 & 9 & 8 & 10 \\
\hline 2014 & $26 / 66$ & 39.4 & 40 & 22 & 3 & 1 & l \\
\hline 2015 & $51 / 178$ & 28.6 & 127 & 38 & 8 & 2 & 3 \\
\hline 2016 & $15 / 108$ & 13.9 & 93 & 12 & 1 & 1 & 1 \\
\hline Total & $147 / 427$ & 34.4 & 280 & 100 & 21 & 12 & 14 \\
\hline
\end{tabular}

* above $0.05 \mu \mathrm{g} / \mathrm{kg}$

Characteristic climatic conditions in Serbia during 2012 affected particularly corn production (Jakšić et al., 2015). Corn contamination with high levels of AF has led to consequent milk contamination with $\mathrm{M}_{1}$. In $73.3 \%$ of samples, maximum EU level for AFM1 in milk $(0.05 \mu \mathrm{g} / \mathrm{kg})$ was exceeded. This result is in accordance with published results of Torovic (2015) where 75\% of samples exceeded concentration of AFM1 of $0.05 \mu \mathrm{g} / \mathrm{kg}$. Somewhat lower frequency of AFM1 contamination was recorded by Tomaševic et al. 2015, while some higher levels were reported by Kos et al., 2015. During the period 2013-2014, Tomašević et al. (2015) analyzed a total of 1,438 milk samples. AFM1 levels exceeded the EU maximum residue limit in $56.3 \%$ of raw milk and $32.6 \%$ of heat-treated milk samples. In the study conducted by Kos et al. (2015) during the first half of 2013, 176 samples of different types of milk were examined in Serbia, and $86.0 \%$ contained AFM1 greater than $0.05 \mu \mathrm{g} / \mathrm{kg}$. After that, in the period 2014 to 2016, gradual decline in the percentage of contaminated samples was observed, ranging from $39.4 \%$ to $13.9 \%$. Although corn gender 2014 and after was not significantly contaminated with AF (Nešić et al., 2015), occasional occurrence of samples with high concentrations of AFM1 was still evident, reaching levels of even over $0.8 \mu \mathrm{g} / \mathrm{kg}$. 


\section{DISCUSSION}

During the crisis with AF in 2013 and even later years, the producers and milk processors faced the problem what to do with contaminated milk. Although regulations on maximum levels of AFM1 do not include milk products, they still refer to the milk intended for processing. Besides that, questions were also asked about the possibility of processing such milk into the safe products. Results of AFM1 examination of milk products indicate that there is no available process which can completely destroy AFM1 (Table 4.). Contrasting data have been reported on the influence of milk products preparation. Numerous investigation showed that the increase of AFM1 levels in cheese is a function of cheese type, the type of unit operations and the amount of eliminated water during processing (Nilchian and Rahimi, 2012; Bakirci, 2001; Deveci 2007). According to Manetta et al. (2009), there is direct correlation between the AFM1 in milk and its level in the final product. Experimental data showed that compared to milk, AFM1 concentration increases in yogurt (sour milk) 2 times, in cheese with a long ripening period 4.5 times, while the concentration of AFM1 in whey decreases by $40 \%$ (Manetta et al., 2009). The study of Deveci and Szegin (2006) revealed that the total AFM1 contents were reduced by about $59-68 \%$ when original skimmed milk was spray-dried. Other authors have different conclusions, i.e., transformation of fluid milk into powder will result in great increase in AFM1 concentration (Campagnollo, 2016). During the production of cheese, AFM1 crosses into the cheese (because it is bound to casein) and whey (as it is soluble in water) (Tokar and Vengust, 2008). There was less AFM1 in cream and butter than in milk. In the soft cheese, the content of AFM1 was 2.5 to 3.3 times higher and in hard cheese 3.9-5.8 times higher than in milk from which the cheese is made (Yousef and Marth, 1989). According to Mohammadi et al. (2009), rennet temperature, press time, and saturated brine $\mathrm{pH}$ affected the amount of AFM1 in cheese production. The combination of pasteurization, the conversion of milk into feta cheese and at least 50 days of preservation in brine leads to a 50\% reduction in initial concentration of AFM1 in milk (Motawee and McMahon, 2009). Studies about the stability of AFM1 in yoghurt during fermentation are controversial, similar as in case of cheese production. In some investigations, AFM1 proved resistant to thermal treatment and slightly acidic conditions in the production of cheese and yoghurt (Colak 2007 Oruc et al., 2006) and an increase of its concentration in yoghurt was observed (Bakirci 2001), while other studies recorded a decreased levels as compared to milk (Govaris et al., 2002). Possible reasons include different $\mathrm{pH}$ of yoghurts and fermentation conditions (Govaris et al., 2002). 
Table 4. Selected studies about stability and fate of AFM1 during dairy processing

\begin{tabular}{|c|c|}
\hline Result & Reference \\
\hline $\begin{array}{l}\text { The AFM1 content in ice-cream and in sherbet re- } \\
\text { mained stable through } 8 \text { months of frozen storage. }\end{array}$ & $\begin{array}{l}\text { Wiseman and } \\
\text { Marth, } 1983\end{array}$ \\
\hline $\begin{array}{l}\text { No significant trends for short- and long-term stabil- } \\
\text { ity of AFM1 in milk powders for } 6 \text { years at }-20^{\circ} \mathrm{C} \text {. }\end{array}$ & $\begin{array}{l}\text { Josephs et } \\
\text { al., } 2005\end{array}$ \\
\hline $\begin{array}{l}\text { Pasteurization at } 63^{\circ} \mathrm{C} \text { for } 30 \text { min caused } \\
<10 \% \text { destruction of AFM1. }\end{array}$ & $\begin{array}{l}\text { Motawee } \\
\text { and McMa- } \\
\text { hon, } 2009\end{array}$ \\
\hline $\begin{array}{l}64.4 \% \text { of AFM1 concentration from } \\
\text { milk was found in cream. } \\
\text { Mean AFM1 level of skim milk was } \\
\text { 3\% higher than those of milk. }\end{array}$ & Bakirci, 2001 \\
\hline $\begin{array}{l}\text { Pasteurization and concentration on } 30-33 \% \\
\text { dry mater reduced } 35-40 \% \text { of AFM1. }\end{array}$ & $\begin{array}{l}\text { Deveci and } \\
\text { Sezgin, } 2006\end{array}$ \\
\hline $\begin{array}{l}\text { Fermentation with different starters to } \mathrm{pH} 4.0 \text { and } 4.5 \\
\text { has impact on reducing AFM1 concentration by } 25 \% \text {. }\end{array}$ & $\begin{array}{l}\text { Jasutiene et } \\
\text { al., } 2006\end{array}$ \\
\hline $\begin{array}{l}\text { AFM1 remained at } 42.87 \% \text { and } 34.73 \% \text { in Turk- } \\
\text { ish White and Kashar cheese samples, respectively. } \\
\text { The change of AFM1 concentration during the white } \\
\text { cheese ripening of } 0-90 \text { days was averagely } 9.8 \% \text {. }\end{array}$ & Colak, 2007 \\
\hline $\begin{array}{l}\text { Loss of the initial amount of AFM1 in milk was esti- } \\
\text { mated at about } 13 \% \text { and } 22 \% \text { by the end of the fermenta- } \\
\text { tion, and } 16 \text { and } 34 \% \text { by the end of storage for } 4 \text { weeks } \\
\text { at } 4^{\circ} \mathrm{C} \text {, for yoghurts with pHs } 4.6 \text { and } 4.0 \text {, respectively. }\end{array}$ & $\begin{array}{l}\text { Govaris et } \\
\text { al., } 2002\end{array}$ \\
\hline $\begin{array}{l}\text { During cheese making, the remain- } \\
\text { ing AFM1 in milk was partitioned: } 2 / 3 \text { re- } \\
\text { tained in the curd and } 1 / 3 \text { going into whey. } \\
22-27 \% \text { AFM1 reduced during storing feta } \\
\text { cheese in brining solutions ( } 8-12 \% \text { w/w salt) } \\
\text { during } 10 \text { days, } 25-29 \% \text { after } 60 \text { days. }\end{array}$ & $\begin{array}{l}\text { Motawee } \\
\text { and McMa- } \\
\text { hon, } 2009\end{array}$ \\
\hline
\end{tabular}

There are no studies on the effects of processing of contaminated milk on the concentration of AFM1 during manufacturing of traditional Serbian products, but there are few studies on the presence of AFM1 in milk products in Serbia. Fifty four samples of white and hard cheese were analyzed in Serbia in May-Jun, 2013. Seven samples (23\%) exceed maximum acceptable level of 
$0.25 \mu \mathrm{g} / \mathrm{kg}$ (Škrbić et al., 2015). In addition to milk, Tomašević et al. (2015) analyzed milk products. Milk powders had the highest mean concentration of AFM1 $(0.847 \pm 1.948 \mu \mathrm{g} / \mathrm{kg})$ and were followed by hard $(0.379 \pm 0.509 \mu \mathrm{g} /$ $\mathrm{kg}$ ) and white cheeses $0.146 \pm 0.170 \mu \mathrm{g} / \mathrm{kg}$. However, based on these studies it is difficult to conclude about the degree of AF transfer into milk products. As can be seen, there is high standard deviation of AFM1 results in milk products, and there is also large difference between the concentration in the milk and milk products. Obviously, the lowest concentration of AFM1 was in yogurt as compared with other products which is in accordance with the presented studies from other countries.

Good nutrition in appropriate animal production system is essential to economically produce a healthy, high-quality product (Mirilović et al., 2015). It is necessary to act preventively in order to avoid milk contamination. Undoubtedly, it is very important to control the quality of feed and storage conditions in view of the presence of aflatoxin. Grains contaminated with AFB1 should not be fed to lactating animals to avoid contamination of milk.

\section{CONCLUSSION}

There is a factual risk of contamination of corn, milk and milk products with AFs in Serbia. In general, one can conclude that neither storage nor processing can fully eliminate AFM1 from milk. Further studies addressing the occurrence and stability of AFM1 in milk products should be carried out in order to evaluate the fate of AFM1 in traditional Serbian milk products. Avoiding economic losses due to processing of contaminated milk is possible if taking into consideration the following conclusions:

1. During milk processing, AFM1 passes from raw milk into cheese, yoghurt and whey.

2. The concentration of AFM1 in cheese depends on the production process and the process of cheese ripening and brining. Recent studies show that AFM1 concentrates in cheese in a large percentage - in contrast to older studies. This is perhaps influenced by the development of new and more accurate methods for determination of AFM1 in cheese. Variations in different studies about AFM1 content in cheese are partially due to the differences in analytical method used to quantify AFM1.

3. The content of AFM1 in yoghurt depends on the $\mathrm{pH}$.

4. The temperature has little effect on reducing the concentration of AFM1, but studies on the presence of AFM1 in pasteurized and UHT milk have always revealed smaller number of contaminated samples of UHT milk. 
5. AFM1 is concentrated in milk powder and remains stable in it for a long time.

6. Sour cream and butter have less AFM1, but there is little information on the percentage.

7. According to several studies, the storage of frozen milk and yoghurt results in the reduction of AFM1concentration of.

8. Milk pasteurization and cheese manufacturing process do not eliminate AFM1, so it is prudent to check the AFM1 incidence in cheese.

\section{ACKNOWLEDGEMENT}

This paper is published as part of the projects of the Ministry of Education, Science and Technological Development of Republic of Serbia No. 031071.

\section{REFERENCES}

1. Arab M., Sohrabvandi S., Mortazavian A.M., Mohammadi R., Rezaei Tavirani M.: Reduction of aflatoxin in fermented milks during production and storage. Toxin Reviews, 31, 3-4, 44-53, 2012.

2. Bakirci I.: A study on the occurrence of aflatoxin M1 in milk and milk products produced in Van province of Turkey. Food Control, 12, 47-51, 2001.

3. Barbiroli A., Bonomi F., Benedetti S., Mannino S., Monti L., Cattaneo T., Lametti S.: Binding of aflatoxin M1 to different protein fractions in ovine and caprine milk. Journal of Dairy Science, 90, 2, 532-540, 2007.

4. Brackett R. E., Marth E. H.: Association of aflatoxin M1 with casein. Zeitschrift für Lebensmittel-Untersuchung und Forschung, 174, 439-441, 1982.

5. Campagnollo F.B., Ganev K.C., Khaneghah A.M., Portela J.B., Cruz A.G., Granato D., Corassin C.H., Oliveira C.A., Sant'Ana A.: The occurrence and the effect of unit operations for dairy products processing on the fate of aflatoxin M1: A review. Food Control, 68, 310-329, 2016.

6. Colak H.: Determination of aflatoxin M1 levels in Turkish White and Kashar Cheeses made of experimentally contaminated raw milk. Journal of Food and Drug Analysis, 15, 2, 163-168, 2007.

7. Creppy E.E.: Update of survey, regulation and toxic effects of mycotoxins in Europe. Toxicology Letters, 127, 19-28, 2002.

8. Deveci O.: Changes in the concentration of aflatoxin M1 during manufacture and storage of White Pickled cheese. Food Control, 18, 1103-1107, 2007.

9. Deveci O., Sezgin E.: Changes in concentration of aflatoxin M1 during manufacture and storage of skim milk powder. Journal of Food Protection, 69, 682-685, 2006. 
10. EC (European Commission): Commission Regulation 165/2010 of $26 \mathrm{Fe}-$ bruary 2010 amending Regulation (EC) No 1881/2006 setting maximum levels for certain contaminants in foodstuffs as regards aflatoxins, O. J., L 50: 8-12, 2010

11. FDA, National Grain and Feed Association Mycotoxin Regulatory Guidance, 2011. https://www.ngfa.org/wp-content/uploads/NGFAComplianceGuideFDARegulatoryGuidanceforMycotoxins8-2011.pdf Accessed 17.02.2017.

12. Galvano F., Galofaro V., Galvano G.: Occurrence and stability of aflatoxin M1 in milk and milk products: A worldwide review, 59, 10, 1079-1090, 1996.

13. Govaris A., Roussi V., Koidis P.A., Botsoglou N.A.: Distribution and stability of aflatoxin M1 during production and storage of youghurt. Food Additives and Contaminants, 19, 11, 1043-1050, 2002.

14. IARC - International Agency for Research on Cancer. IARC Monograph on the Evaluation of Carcinogenic Risk to Humans. 82, 171, 2002.

15. Jakšić S., Živkov-Baloš M., Prica N., Mašić Z., Nešić K., Jajić I., Abramović B.: The influence of climatic factors in Serbia on mycotoxin production. U: Tamaš Petrović, urednik, Proceedings, First International Symposium of Veterinary Medicine 'One Health - New Challenges' (ISVM2015), May 21-23, Vrdnik, Scientific Veterinary Institute 'Novi Sad', 2015, 166-172.

16. Jasutiene I., Garmiene G., Kulikauskiene M.: Pasteurisation and fermentation effects on Aflatoxin M1 stability. Milchwissenschaft-Milk Science International, 61, 1, 75-79, 2006.

17. Josephs R.D., Ulberth F., Van Egmond H.P., Emons H.: Aflatoxin M1 in milk powders: processing, homogeneity and stability testing of certified reference materials. Food Additives and Contaminants, 22, 9, 864-874, 2005.

18. Kos J., Lević J., Đuragić O., Kokić B., Miladinović I.: Occurrence and estimation of aflatoxin M1 exposure in milk in Serbia. Food Control, 38, 41-46, 2014.

19. Manetta A.C., Giammarco M., Di Giuseppe L., Fusaro I., Gramenzi A., Formigoni A., Vignola G., Lambertini L.: Distribution of aflatoxin M1 during Grana Padano cheese production from naturally contaminated milk. Food Chemistry, 113, 595-599, 2009.

20. Mirilović M., Teodorović V, Marković R., Aleksić-Agelidis A., Vejnović B., Đurić S., Jovanović D.: Economic evaluation of rainbow trout (Oncorhynchus mykiss) farming fed with different composition feed. Arhiv veterinarske medicine, 8, 2, 55-65, 2015.

21. Mohammadi H., Alizadeh M., Bari M. R., Khosrowshahi A., Tadjik H.: Optimization of the process variables for minimizing of the aflatoxin M1 content in Iranian white brine cheese. Journal of Agricultural Science and Technology, 11, 181-190, 2009. 
22. Motawee M.M., McMahon D.J.: Fate of aflatoxin M1 during manufacture and storage of feta cheese. Journal of Food Science, 74, 5, T42-T45, 2009.

23. Nešić K., Jakšić S., Živkov-Baloš M., Prunić B.: Mycotoxicological assessment of feed in Serbia in 2014 in the light of new legislation. Proceedings, U: Tamaš Petrović, urednik, Proceedings, First International Symposium of Veterinary Medicine 'One Health - New Challenges' (ISVM2015), May 21-23, Vrdnik, Scientific Veterinary Institute 'Novi Sad', 2015, 124-132.

24. Nilchian Z., Rahimi E.: Aflatoxin M1 in yoghurts, cheese and ice-cream in Shahrekord-Iran. World Applied Sciences Journal, 19, 5, 621-624, 2012.

25. Oruc H.H., Cibik R., Yilmaz E., Kalkanli O.: Distribution and stability of Aflatoxin $\mathrm{M} 1$ during processing and ripening of traditional white pickled cheese. Food Additives and Contaminants, 23, 190-195, 2006.

26. Prandini A., Tansini G., Sigolo S., Filippi L., Laporta M., Piva G.: On the occurrence of aflatoxin M1 in milk and dairy products. Food and Chemical Toxicology, 47, 984-991, 2009.

27. Rama A., Latifi F., Bajraktari D., Ramadani N.: Assessment of aflatoxin M1 levels in pasteurized and UHT milk consumed in Prishtina, Kosovo. Food Control, 57, 351-354, 2015.

28. „Službeni glasnik RS” 28/2011: Pravilnik o maksimalno dozvoljenim količinama ostataka sredstava za zaštitu bilja u hrani i hrani za životinje i o hrani za životinje za koju se utvrđuju maksimalno dozvoljene količine ostataka sredstava za zaštitu bilja.

29. „Službeni glasnik RS” 20/2013: Pravilnik o izmeni Pravilnika o maksimalno dozvoljenim količinama ostataka sredstava za zaštitu bilja u hrani i hrani za životinje i o hrani i hrani za životinje za koju se utvrđuju maksimalno dozvoljene količine ostataka sredstava za zaštitu bilja.

30. „Službeni glasnik RS” 29/2014: Pravilnik o maksimalno dozvoljenim količinama ostataka sredstava za zaštitu bilja u hrani i hrani za životinje i o hrani za životinje za koju se utvrđuju maksimalno dozvoljene količine ostataka sredstava za zaštitu bilja.

31. „Službeni glasnik RS” 39/2014: Pravilnik o izmeni Pravilnika o maksimalno dozvoljenim količinama ostataka sredstava za zaštitu bilja u hrani i hrani za životinje i o hrani i hrani za životinje za koju se utvrđuju maksimalno dozvoljene količine ostataka sredstava za zaštitu bilja.

32. „Službeni glasnik RS” 72/2014: Pravilnik o izmeni Pravilnika o maksimalno dozvoljenim količinama ostataka sredstava za zaštitu bilja u hrani i hrani za životinje i o hrani i hrani za životinje za koju se utvrđuju maksimalno dozvoljene količine ostataka sredstava za zaštitu bilja.

33. „Službeni glasnik RS” 84/2015: Pravilnik o izmeni Pravilnika o maksimalno 
dozvoljenim količinama ostataka sredstava za zaštitu bilja u hrani i hrani za životinje i o hrani i hrani za životinje za koju se utvrđuju maksimalno dozvoljene količine ostataka sredstava za zaštitu bilja.

34. „Službeni glasnik RS” 35/2016: Pravilnik o izmeni Pravilnika o maksimalno dozvoljenim količinama ostataka sredstava za zaštitu bilja u hrani i hrani za životinje i o hrani i hrani za životinje za koju se utvrđuju maksimalno dozvoljene količine ostataka sredstava za zaštitu bilja.

35. „Službeni glasnik RS” 81/2016: Pravilnik o izmeni Pravilnika o maksimalno dozvoljenim količinama ostataka sredstava za zaštitu bilja u hrani i hrani za životinje i o hrani i hrani za životinje za koju se utvrđuju maksimalno dozvoljene količine ostataka sredstava za zaštitu bilja.

36. „Službeni glasnik RS” 21/2017: Pravilnik o izmeni Pravilnika o maksimalno dozvoljenim količinama ostataka sredstava za zaštitu bilja u hrani i hrani za životinje i o hrani i hrani za životinje za koju se utvrđuju maksimalno dozvoljene količine ostataka sredstava za zaštitu bilja.

37. Škrbić B., Antić I., Živančev J.: Presence of aflatoxin M1 in white and hard cheese samples from Serbia. Food Control, 50, 111-117, 2015.

38. Tolkar K.G., Vengušt A.: The presence of yeasts, moulds and aflatoxin M1 in raw milk and cheese in Slovenia. Food Control, 19, 570-577, 2008.

39. Tomašević I., Petrović J., Jovetić M., R., Milojević M., Miočinović J.: Two year survey on the occurrence and seasonal variation of aflatoxin M1 in milk and milk products in Serbia. Food Control, 56, 64-70, 2015.

40. Torović LJ. Aflatoxin M1 in processed milk and infant formulae and corresponding exposure of adult population in Serbia in 2013-2014. Food Additives \& Contaminants: Part B, 8, 4, 235-244, 2015.

41. Yousef A.E., Marth E.H.: Stability and degradation of aflatoxin M1. U: H.P. van Egmond, Mycotoxin in dairy products, London and New York: Elsevier Applied Science, str. 127-161, 1989.

42. Van Egmond H.P., Paulish W.E.: Mycotoxins in milk and milk products. Netherlands Milk and Dairy Journal, 40, 175-188, 1986.

43. Wiseman D.W., Marth E.H.: Stability of aflatoxin M1 during manufacture and storage of ice-cream and sherbet. Zeitschrift für Lebensmittel-Untersuchung und Forschung, 177, 1, 22-24, 1983.

44. Živkov-Baloš M., Mihaljev Ž., Kovačević M., Bugarski D.: Ekskrecija aflatoksina mlekom: rizik za potrošače. Arhiv veterinarske medicine, 1, 1, 6468, 2008. 
